\title{
Evaluation of Fungicides for the Control of Bakanae Disease of Rice Caused by Fusariummoniliforme (Sheldon)
}

\author{
MS Hossain ${ }^{*}$, M Ayub Ali², MIU Mollah¹, M A I Khan ${ }^{3}$ and A K M Sajjadul Islam
}

\begin{abstract}
Bakanae is one of the major diseases of rice in Bangladesh and causes substantial yield loss. To control the disease eleven fungicides from different fungicidal groups were evaluated for their efficacy against seed-borne fungus, F. moniliforme as seed treatment both in the laboratory and in the seed-bed during 2011 and 2012. In the laboratory the fungicides were evaluated at three concentration levels viz 2.5, 3.0 and $3.5 \mathrm{gm} / \mathrm{L} / \mathrm{kg}$ seeds. Overall performance of the fungicides was found to be better in suppressing the seed-borne F. monilifome and increasing seed germination. Among the fungicides, Bavistin, Sunphanate, Nativo and Carzeb completely inhibiting the growth of $F$. moniliformeinvitro condition at their low $(2.5 \mathrm{gm} / \mathrm{L})$ concentration. Efficacy of the fungicides reduced to some extent when the treated seeds were washed with fresh water except Bavistin. Maximum (85\%) average germination was found in Bavistin and Greenzeb treated seeds. The promising fungicides further evaluated to control seedling infection at low $(2.5 \mathrm{gm} / \mathrm{L})$ concentration and resulted significant reduction of bakanae infected seedlings in pot soil and in seed bed.
\end{abstract}

Key words: Fungicides, bakanae disease, rice, control

\section{INTRODUCTION}

Bakanae disease of rice caused by Fusariummoniliforme (Sheldon) [TeleomorphGibberellafujikuroi] is one of the major rice diseases in many rice growing countries including Bangladesh (Miahet al., 1985; Singh and Sunder, 1997). In Bangladesh the disease was first detected in 1953 by the Mycology and Plant Pathology Division of Bangladesh Agricultural Research Institute and was mostly localized in Aus season (Anon, 1958). Now-a-days it is spread all the seasons and the incidence and severity are quite serious (Momotaz, 2005). The most striking symptom of this disease is yellowing and abnormal elongation of infected rice seedling, which led to the name bakanae. The other symptoms of this disease are foot rot, seedling rot, grain sterility and grain discoloration $(\mathrm{Ou}$, 1985). Even in open field nurseries, one of the problems encountered by farmers in the control of bakanae disease is the difficulty in distinguishing infected seedlings from healthy plants, because there are no obvious symptoms of infected seedlings except the height or slight pale yellowing at the stage of transplanting (Kim, 1981).Under favourable conditions, it causes substantial damage and as high as $95.40 \%$ yield loss has been estimated in India (Sigh and Sunder, 1997), $15 \%$ in Thailand (Ou, 1985), 20-50\% in Japan (Ito and Kumara, 1931) and 21-26.7\% in Bangladesh (Latifet al., 2006). The pathogen can be both seed-borne and soil borne. But the role of infected seed as a source of inoculum for this disease is well documented (Santos, 1957; Nathet al., 1970; Winter et al., 1974) and is also the main means of spreading the disease from field to field. Generally, the seed-borne inocula provide initial foci for seedling infection. Infected plants in the field, that reach heading produce enormous amount of inocula, which infect the developing grains results in deep infection on the seed(Kim, 1981).

Bakanae disease of rice recently gained economic importance due to large scale cultivation of susceptible rice varieties. Therefore, it is very much important to manage the disease. The other way to secure the crop from this disease is fungicidal seed treatment. It is found that untreated seeds were heavily infected with an overall $94.5 \%$ with disease, whereas disease incidence in treated nursery was only 5.5\% (Gill and Parvez, 1992). Therefore, efforts so far were given on seed treatment. There are few reports on the in vitro toxicity of fungicides to $F$. moniliforme (Garibaldi, 1985; Sasaki, 1987). Fungicides of organo-marcurial and benzimidazol groups have generally been reported to be effective against this disease $(\mathrm{Ou}, 1985)$. However, disease control at different locations varied with fungicides, their concentration, period of soaking and isolates of pathogen (Kauraw, 1981 andWada et al., 1990).

\footnotetext{
1Training Division, Bangladesh Rice Research Institute, Gazipur 1701.2Department of Plant Pathology, Bangladesh Agricultural University, Mymensingh 5022. ${ }^{3}$ Plant Pathology Division, Bangladesh Rice Research Institute, Gazipur 1701.4BRAC Agricultural Research and Development Centre, Gazipur 1701. *Corresponding author's E-mail: sahadatbrri@yahoo.com
} 
Furthermore, in Bangladesh, there are no registered fungicides as seed treatment for $F$. moniliforme. Keeping in view the importance of fungicides for disease control, studies were undertaken on the efficacy of fungitoxicants against bakanae disease to evaluate the in vitro efficacy of different fungicides.

\section{METHODOLOGY}

The experiment was conducted in the Plant Pathology Laboratory at Bangladesh Rice Research Institute (BRRI) and farmer's field. Efficacy of fungicides was assessed to control a) seed-borne infection, b) seedling infection in pot and c) seedling infection in seed-bed.

Seed-borne infection.About $12 \mathrm{~kg}$ seeds of BR1 were collected from bakanae infected fields. About $250 \mathrm{gm}$ of seeds was taken in a cloth bag and 33 cloth bags were used. Eleven fungicides of different fungicidal groups were tested. Table 1 presents the details about the fungicides. Three different suspensions of each fungicide were prepared by adding 2.5, 3.0 and $3.5 \mathrm{gm}$ commercial fungicide/ $\mathrm{L}$ water for each $\mathrm{kg}$ seeds. The seeds were submerged under the fungicidal suspension for overnight (10-12 hrs). Afterward the excess suspension was drained out. After soaking for over night one part of fungicides treated seeds were washed with sterilized distilled water for 3-4 times and dried in shed. Other parts of treatedseeds, also dried in shed, were kept unwashed. Control treatment was provided by treating seed using sterilized distilled water only without fungicides. The treated seeds were tested by blotter method to detect $F$. moniliformefollowing international rules for testing seed health(ISTA, 2000). Number of germinated seeds on which $F$. moniliforme grew was recorded. For proper identification temporary slides were prepared from the fungal colony, observed under compound microscope and identified following the method described by Nathet al. (1970).

Table 1. Fungicides used for seed treatment.

\begin{tabular}{|c|c|c|c|}
\hline Chemical group & Active ingredient & Trade name & Doses $(\mathrm{gm} / \mathrm{L})^{*}$ \\
\hline Benzimidazole & Carbendazim & Bavistin 50WP & $2.5,3.0,3.5$ \\
\hline Carbamate & Thiophenate methyl & Sunphanate 70WP & $2.5,3.0,3.5$ \\
\hline Not found & Tricyclazole & Trigger $75 \mathrm{WP}$ & $2.5,3.0,3.5$ \\
\hline Mancozeb & Dithiocarbamate & Greenzeb & $2.5,3.0,3.5$ \\
\hline Dithiolane & Isoprothioline & Sunthio $40 \mathrm{EC}$ & $2.5,3.0,3.5$ \\
\hline Dicarboximide & Iprodione & Rovral 50WP & $2.5,3.0,3.5$ \\
\hline Inorganic & Copper oxichloride & Gunner & $2.5,3.0,3.5$ \\
\hline Mixed & Mancozeb $63 \%$ + Carbendazim 12\% & Carzeb $75 \mathrm{WP}$ & $2.5,3.0,3.5$ \\
\hline Mixed & Tabuconazole $50 \%+$ Trifloxystrobin & Nativo $75 \mathrm{WP}$ & $2.5,3.0,3.5$ \\
\hline Mixed & $55 \%$ Metiram+ 5\% Pyraclostrobin & Cabrio 60 WG & $2.5,3.0,3.5$ \\
\hline
\end{tabular}




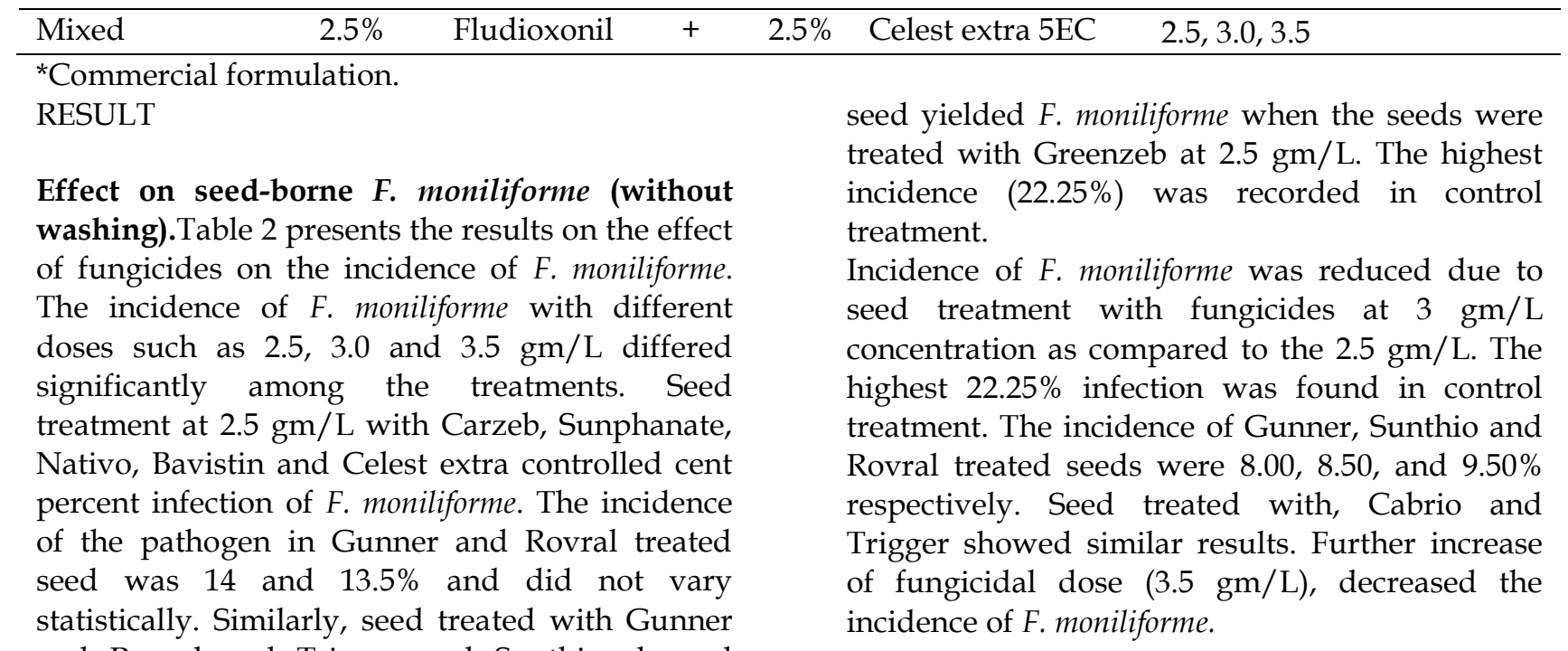
and Rovral and Trigger and Sunthio showed identical results. On the other hand, only $1.25 \%$

Table 2.Effect of fungicides on seed-borne infection of Fusariummoniliforme in rice seeds (without washing).

\begin{tabular}{l|c|c|c}
\hline \multirow{2}{*}{ Chemical } & \multicolumn{3}{|c}{ \% incidence at three doses of fungicides $(\mathrm{gm} / \mathrm{L})$} \\
\cline { 2 - 4 } & 2.50 & 3.00 & 3.50 \\
\hline Carzeb 75WP & $0.00 \mathrm{e}$ & $0.00 \mathrm{~d}$ & $0.00 \mathrm{~g}$ \\
Sunphanate 70WP & $0.00 \mathrm{e}$ & $0.00 \mathrm{~d}$ & $0.00 \mathrm{~g}$ \\
Nativo 75WG & $0.00 \mathrm{e}$ & $0.00 \mathrm{~d}$ & $0.00 \mathrm{~g}$ \\
Bavistin 50 WP & $0.00 \mathrm{e}$ & $0.00 \mathrm{~d}$ & $0.00 \mathrm{~g}$ \\
Celest Extra 050FS & $0.00 \mathrm{e}$ & $0.00 \mathrm{~d}$ & $0.00 \mathrm{~g}$ \\
Trigger 75WP & $7.25 \mathrm{c}$ & $3.50 \mathrm{c}$ & $2.93 \mathrm{ef}$ \\
Gunner & $14.0 \mathrm{~b}$ & $8.00 \mathrm{~b}$ & $6.50 \mathrm{c}$ \\
Sunthio 40EC & $9.00 \mathrm{c}$ & $8.50 \mathrm{~b}$ & $9.75 \mathrm{~b}$ \\
Cabrio 60WG & $4.18 \mathrm{~d}$ & $1.75 \mathrm{~cd}$ & $1.50 \mathrm{fg}$ \\
Rovral & $13.50 \mathrm{~b}$ & $9.50 \mathrm{~b}$ & $5.00 \mathrm{~d}$ \\
Greenzeb & $1.25 \mathrm{~d}$ & $1.25 \mathrm{~d}$ & $1.00 \mathrm{fg}$ \\
Control & $22.25 \mathrm{a}$ & $22.25 \mathrm{a}$ & $22.25 \mathrm{a}$ \\
\hline
\end{tabular}

Means followed by same letter in a column did not differ at the $5 \%$ level of significance by DMRT.

Effect on seed-borne $F$. moniliforme (after washing).Table 3 presents the performance of the fungicides after washing of treated seeds. Different fungicides had significant effect on the incidence of $F$. moniliforme. Cent percent inhibition of the pathogen $F$. moniliformewas found when the seeds were treated with Bavistin at $2.5 \mathrm{gm} / \mathrm{L}$ followed by Sunphanate, Carzeb and Nativo. The incidence of the pathogen by Celest Extra, Trigger and Cabrio treated seeds were 6.75, 12.75 and $9.50 \%$ respectively. These were statistically significant. The incidence was identical in control, Rovral and Gunner treated seeds. At $3 \mathrm{gm} / \mathrm{L}$, all the fungicides significantly reduced the incidence of $F$. moniliformeas compared with $2.5 \mathrm{gm} / \mathrm{L}$. Gunner treated seed yielded $18.50 \%$ infection, which was similar to seed treated with Rovral. There was no difference between the treatment of Rovral and control. In further increase of the dose $(3.5 \mathrm{gm} / \mathrm{L})$, none of the fungicides completely eradicated the infection of the pathogen except Sunphanate. Sunphanate showed cent percent inhibition of $F$. moniliforme at $3.5 \mathrm{gm} / \mathrm{L}$ followed by Carzeb and Greenzeb. Although it's corresponding low dose did not show complete inhibition. The infection in Gunner and Rovral treated seeds did not differ statistically. Similarly, the performance of Trigger and Sunthio at dose $3.5 \mathrm{gm} / \mathrm{L}$ was identical. 
Table 3.Effect of fungicides on seed-borne infection of Fusariummoniliforme in rice seeds (after washing).

\begin{tabular}{|c|c|c|c|}
\hline \multirow[t]{2}{*}{ Chemical } & \multicolumn{3}{|c|}{$\%$ incidence at three doses of fungicides $(\mathrm{g} / \mathrm{L})$} \\
\hline & 2.50 & 3.00 & 3.50 \\
\hline Carzeb 75WP & 3.75 ef & $3.50 \mathrm{fg}$ & $1.25 \mathrm{e}$ \\
\hline Sunphanate 70WP & $1.75 \mathrm{fg}$ & $1.25 \mathrm{~g}$ & $0.00 \mathrm{e}$ \\
\hline Nativo $75 W G$ & $2.25 \mathrm{fg}$ & $2.25 \mathrm{fg}$ & $2.00 \mathrm{e}$ \\
\hline Bavistin 50WP & $0.00 \mathrm{~g}$ & $0.00 \mathrm{~g}$ & $0.00 \mathrm{e}$ \\
\hline Celest Extra 050FS & $6.75 \mathrm{~d}$ & 8.75 de & $5.50 \mathrm{~d}$ \\
\hline Trigger 75WP & $12.75 \mathrm{~b}$ & $13.25 \mathrm{c}$ & $11.25 \mathrm{c}$ \\
\hline Gunner & $25.50 \mathrm{a}$ & $18.50 \mathrm{~b}$ & $16.00 \mathrm{~b}$ \\
\hline Sunthio 40EC & $12.00 \mathrm{bc}$ & 10.50 cde & $9.50 \mathrm{c}$ \\
\hline Cabrio 60WP & $9.50 \mathrm{c}$ & 6.50 ef & $5.00 \mathrm{~d}$ \\
\hline Rovral & $24.50 \mathrm{a}$ & $22.50 \mathrm{ab}$ & $15.00 \mathrm{~b}$ \\
\hline Greenzeb & $5.50 \mathrm{de}$ & $4.25 \mathrm{fg}$ & $2.00 \mathrm{e}$ \\
\hline Control & $26.50 \mathrm{a}$ & $26.50 \mathrm{a}$ & $26.50 \mathrm{a}$ \\
\hline
\end{tabular}

Means followed by same letter in a column did not differ at the $5 \%$ level of significance by DMRT.

Effect of fungicides on seed germination.

Table 4 presents the effects of fungicides on seed germination. At $2.5 \mathrm{gm} / \mathrm{L}$ all fungicides significantly increased the germination percentage over control. The highest germination $(89.50 \%)$ was found in Greenzeb treated seeds. These were statistically similar in seed germination for all other fungicidal treated seeds except Triger. In case of Triger, the germination was $68 \%$ and did not vary significantly with the germination of control treatment. The lowest germination $(67.50 \%)$ was recorded in control. All fungicides also increased seed germination at the dose of $3 \mathrm{gm} / \mathrm{L}$. However, at fungicidal dose of $3.50 \mathrm{gm} / \mathrm{L}$, seed germination decreased in case of most of the fungicides.

Table 4.Effect of fungicides and their doses as seed treatment on seed germination.

\begin{tabular}{l|ccc}
\hline \multirow{2}{*}{ Fungicide } & \multicolumn{3}{|c}{ \% seed germination at different rates of fungicides $(\mathrm{gm} / \mathrm{L})$} \\
\cline { 2 - 4 } & 2.50 & 3.00 & 3.50 \\
\hline Carzeb 75WP & $87.50 \mathrm{ab}$ & $79.00 \mathrm{~b}$ & $71.00 \mathrm{de}$ \\
Sunphanate 70WP & $80.50 \mathrm{adc}$ & $80.50 \mathrm{ab}$ & $83.50 \mathrm{ab}$ \\
Nativo 75WP & $83.50 \mathrm{ab}$ & $83.00 \mathrm{ab}$ & $75.00 \mathrm{~cd}$ \\
Bavistin 75WP & $85.00 \mathrm{ab}$ & $85.25 \mathrm{ab}$ & $84.75 \mathrm{ab}$ \\
Celest Extra 050FS & $83.00 \mathrm{ab}$ & $84.25 \mathrm{ab}$ & $82.75 \mathrm{abc}$ \\
Trigger 75WP & $68.00 \mathrm{~d}$ & $78.25 \mathrm{~b}$ & $70.00 \mathrm{de}$ \\
Gunner & $79.50 \mathrm{abc}$ & $80.00 \mathrm{~b}$ & $72.50 \mathrm{de}$ \\
Sunthio 40EC & $72.50 \mathrm{~cd}$ & $85.00 \mathrm{ab}$ & $81.50 \mathrm{abc}$ \\
Cabrio 60WP & $84.00 \mathrm{ab}$ & $81.50 \mathrm{ab}$ & $82.00 \mathrm{abc}$ \\
Rovral & $83.50 \mathrm{ab}$ & $83.00 \mathrm{ab}$ & $80.50 \mathrm{abc}$ \\
Greenzeb & $89.50 \mathrm{a}$ & $89.00 \mathrm{a}$ & $77.50 \mathrm{bc}$ \\
Control & $67.50 \mathrm{~d}$ & $67.50 \mathrm{c}$ & $67.50 \mathrm{e}$ \\
\hline
\end{tabular}

Means followed by same letters in a column did not differ at the $5 \%$ level of significance by DMRT.

Figure 1 shows the mean of the germination as influenced by different fungicides. Maximum $85 \%$ germination was found in Greenzeb and Bavistin treated seeds. The germination was $83,82,82$ and $81 \%$ respectively in Cabrio, Rovral,
Sunphanateand Nativo treated seeds respectively. Seed treated with Carzeb and Sunthio had 79 and $80 \%$ germination. Minimum $68 \%$ germination was recorded in control treatment. 


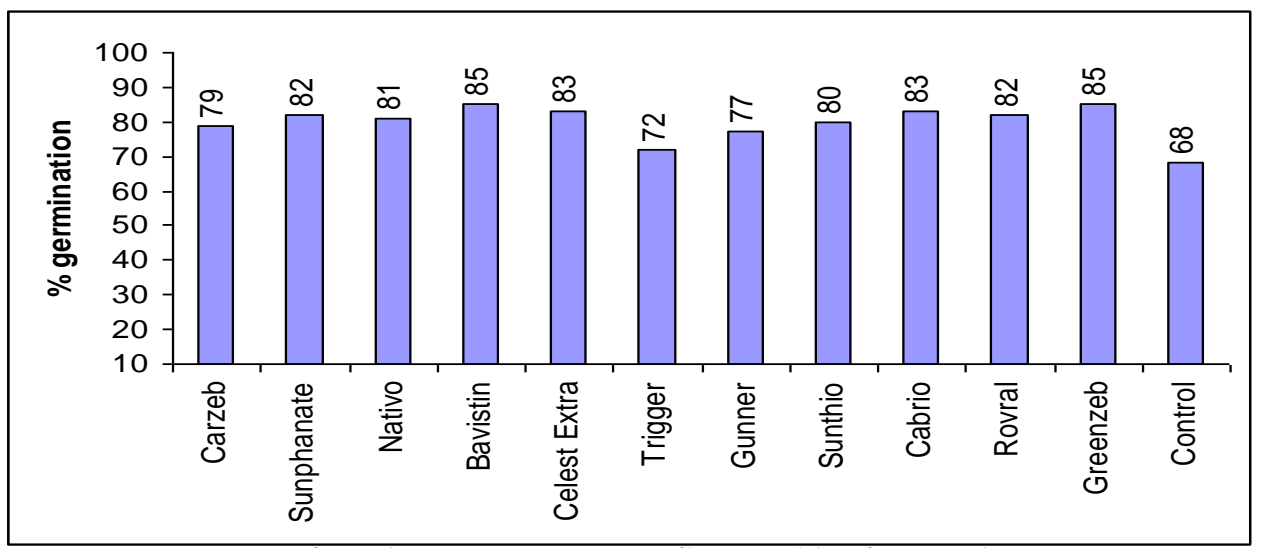

Fig. 1. Mean of seed germination as influenced by fungicide treatment.

Effect of promising fungicides on bakanae (Pot experiment). Table 5 presents the effect of selected fungicides on infected rice seeds tested on pot soil. Seed germination and incidence of bakanae infected seedlings at 10 and 20 days after seeding (DAS) were observed. The highest germination $(85.83 \%)$ was found in Bavistin treated seeds followed by Sunphanate (83\%) treated seed. The lowest germination $(65.33 \%)$ was recorded from control treatment. There was 82.50 and $80.17 \%$ germination in Nativo and Carzed treated seeds. There was no infected seedling from treated seeds even at 20 DAS. However, in control treatment there was 31.5 and $42.36 \%$ bakanae infected seedlings at 10 and 20 DAS respectively.

Table 5.Effect of fungicides as seed treatment on the incidence of bakanae seedlings on pot soil.

\begin{tabular}{|c|c|c|c|}
\hline \multirow[t]{3}{*}{ Treatment } & \multirow{3}{*}{$\begin{array}{c}\text { Germination } \\
(\%)\end{array}$} & \multirow{2}{*}{\multicolumn{2}{|c|}{$\begin{array}{c}\% \text { incidence of bakanae } \\
\text { Days after seeding (DAS) }\end{array}$}} \\
\hline & & & \\
\hline & & 10 & 20 \\
\hline Bavistin 50WP & $85.83 \mathrm{a}$ & $0 \mathrm{~b}$ & $0 \mathrm{~b}$ \\
\hline Sunphanate 70WP & $83.00 \mathrm{a}$ & $0 \mathrm{~b}$ & $0 \mathrm{~b}$ \\
\hline Carzeb 75WP & $80.17 b$ & $0 \mathrm{~b}$ & $0 \mathrm{~b}$ \\
\hline Nativo 75WG & $82.50 \mathrm{~b}$ & $0 \mathrm{~b}$ & $0 \mathrm{~b}$ \\
\hline Control & $65.33 c$ & $31.5 \mathrm{a}$ & $42.36 \mathrm{a}$ \\
\hline
\end{tabular}

Means followed by same letter in a column do not differ at the $5 \%$ level of significance by DMRT.

Effect of promising fungicides on bakanae in seed-bed.The performance of selected fungicides for seed treatment was compared to untreated seeds in the seed-beds. The seeds were treated with the fungicides before sowing in the seedbed. Table 6 presents the results of fungicidal treatment of rice seeds on bakanae incidence in seed-bed. All fungicides significantly reduced bakanae disease in seed-bed. In case of 2009, the lowest bakanae infected seedlings $(0.67 \%)$ was found in the seed-bed, where Bavistin and
Sunphanate treated seeds were sown. The incidence of bakanae was $1.3 \%$ and $1.0 \%$ in Carzeb and Nativo treated seed-bed. In 2010, again Bavistin and Sunphanate treated seed-bed, yielded significantly the lowest infection $(1 \%)$. Carzeb treated seed-bed yielded 2\% infection whereas it was $1.67 \%$ in Nativo treated seed. The highest bakanae infected seedlings (6\%) was found in control seed-bed.

Table 6.Effect of fungicides as seed treatment on the incidence of bakanae disease in seed-bed.

\begin{tabular}{|c|c|c|}
\hline \multirow[t]{2}{*}{ Treatment } & \multicolumn{2}{|c|}{$\%$ incidence of bakanae infected seedling } \\
\hline & 2009 & 2010 \\
\hline Bavistin 50WP & $0.67 \mathrm{~b}$ & $1.00 \mathrm{~b}$ \\
\hline Carzeb 75WP & $1.33 \mathrm{~b}$ & $2.00 \mathrm{~b}$ \\
\hline Sunphanate 70WP & $0.67 \mathrm{~b}$ & $1.00 \mathrm{~b}$ \\
\hline Nativo 75WG & $1.00 \mathrm{~b}$ & $1.67 \mathrm{~b}$ \\
\hline Control & $7.00 \mathrm{a}$ & $6.00 \mathrm{a}$ \\
\hline
\end{tabular}

Means followed by same letter in a column, did not differ at the $5 \%$ level of significance by DMRT. 


\section{DISCUSSION}

Bakanae disease of rice caused by Fusariummoniliforme occurs in almost all rice growing countries of the world including Bangladesh. The causal agent of the disease is seed-borne pathogens and can caused reduction in seed germination, attack mature plants and developing seeds (Khan et al., 1990). The fungicides have great impact on the germination of seeds by suppressing the seed-borne pathogen and enhance the overall germination percentage. Thus, the impact of different fungicides on the inhibition of seed-borne F. moniliforme as well as seed germinationwas studied using standard blotter method. The results revealed a significant response in terms of inhibition of seed-borne $F$. moniliforme. Among the fungicides Bavistin, Sunphanate, Carzeb and Nativo completely eradicated the pathogen from the infected seeds at low $(2.5 \mathrm{gm} / \mathrm{L})$ dose. The other fungicides having higher concentrations also reduced the pathogen significantly. Effectiveness of fungicides against $F$. moniliformehas been suggested by many researchers (Haqueet al., 1980; Sarker, 1986; Bhalliet al., 2001; Akter, 2001; Latifet al., 2007; Shakahwat, 2009). They documented that seed treatment with Bavistin and Sunphanate consistently provided good protection against $F$. moniliforme and other fungi associated with rice seeds. The findings of Biswas and Das (2002) also strongly support the results of the study. They stated that Bavistin, Emisan-6 and Benomyl were the most inhibitory against $F$. moniliforme.

In Bangladesh, broadcasting of sprouted seeds in puddled seed-bed is a common practice for raising rice seedling. This practice, probably have an adverse effect on the efficacy of fungicides of treated seeds. Therefore, in present study, treated seeds were also subject to surface washing before planting for fungal recovery. It was observed that surface washing reduced the effectiveness of the fungicides to some extent. However, even after washing, in case ofBavistin treated seeds (seeds pre soaked in Bavistin solution), the efficacy was found to remain unchanged. This might be the efficacy of Bavistin on seed-borne inocula of $F$. moniliforme is comparatively quick, which might have killed the pathogen by over night soaking. These results are in agreement with the findings of Sunder et al. (1998); Latifet al. (2007). They reported that Carbendazim was best while the treated seeds were washed after treatment. Therefore, under such condition Bavistin could be used to get better disease control. Regarding germination, it was found to be better at $2.5 \mathrm{gm} / \mathrm{L}$ dose $(89.9 \%)$ of Greenzeb. By increasing the fungicidal dose $(3 \mathrm{gm} / \mathrm{L})$ the germination percentage increased. Although further increase of dose most of the cases germination percentage decreased. The findings are in accordance with the result of Bhalliet al. (2001) and Gill el al. (1999). Bavistin andGreenzed exhibited best results with maximum $(85 \%)$ mean germination followed by Celest Extra. The results were in accordance with those of Iqbalet al. (2013). Similar studies also carried out by Ilyas and Iftikhar (1997) with fifteen different fungicides.

\section{CONCLUSIONS}

Bakanae is one of the most destructive disease of rice in Bangladesh and the causal agent of the disease is seed borne. Seed treatment with Bavistin, Sunphanate, Nativo and Carzeb completely eradicate the pathogen from the seeds. These findings are important especially concerning a seed certification programme in which seed lot are certified on the basis of field infection. Finally, controlled experiments are needed to draw more general conclusion.

\section{REFERENCES}

Anonymous. 1958. Annual report of the Mycology and Plant Pathology Division, Agricultural Research Institute, Govt, of East pakistan for the year 1957-58.

Akter, S, M A T Mia and I Hossain. 2001. Chemical control of grain discolouration in rice. Bangladesh J. Seed Sci. and Tech. 5 (1 \& 2): 41-45.

Bhalli, J A, M Auranzeb, M B Ilyeas. 2001. Chemical control of bakanae disease of rice caused by Fusariummoniliforme. On line J. Biol. Sci. 1(6): 483-484.

Biswas, S, S N Das. 2002. Efficacy of Fungicides for the control of bakanae disease of rice. Annals Plant Protec. Sci. 10(2): 288-290.

Gill, M A, A Wahid, M S Javed and T Z Khan. 1999. Major disease of rice in the Punjab and their managemantstrategis. In: Proc. 2nd Natl. Conf. Plant Pathol., Sept. 27-29. 1999, Univ. Agric. Faisalabad

Garibaldi, A. 1985.Control of seed-borne Drechsleraoryzae and Fusariummoniliforme on rice in Northern Italy.Meded.Facul.Landb.Rijksuniv.Gent. 50: 1251-1257.

Haque, M A, S A Miah, M MRahman. 1980. Seed treatment for the control of bakanae disease of rice. 4th and 5th Bangladesh Science Conference, Rajshahi. Bangladesh.

Ito, $\mathrm{S}$ and J Kimura. 1931. Studies on the bakanae disease of the rice plant. Rep. Hokkaido Natn. Agric. Exp. Sta. 27: 1-95+5 
ISTA. 2000. International Seed Testing Association, international rules for seed testing, Seed Science Tech. 335.

Ilyas, M B and K Iftikhar. 1997. Screening of rice germplasm and fungitoxicants against bakanae disease of rice. Pak. J. Phytopath. 9 (1): 67-73.

Iqbal, M, N Javed, I Y Saleem, T S Shahbaz and W Waqus. 2013. Studies on chemical control of bakanae disease (Fusariummoniliforme) of rice in Pakistan. Pak. J. Phytopathol. 25(02): 146-154.

Kauraw, L P. 1981. Effect of length of treatment and fungicide concentration on seed germination and incidence of foot rot disease of rice.Intern. Rice Res. Newsl. 6(6): 15.

Kim, C K. 1981. Ecological studies of bakanae disease of rice caused by Gibberellafujikorai. Korean J. Plant Protec. 20: 146-151.

Khan, T Z, M A Gill, S I Yasin, M G Khan. 1995. Effect of seed treatment on bakanae disease incidence and paddy yield. Pakistan J. Phytopath. 7(2): 124-127.

Latif, M A, M A T Mia, M Hossain. 2006. In abstract: Yield loss, integrated management approaches and development of a quick screening method of bakanae disease of rice in Bangladesh. 2nd International rice congress, October 9-13, 2006, New Delhi, India p. 409.

Latif, M A, M S Kabir, N R Sharma and M A Hossain. 2007. Integrated management of five major disease of rice (in Bangla). Bangladesh Rice Research Institute. Pub.no. 170, p. 28.

Miah, S H, A K M Shahjahan, M A Hossain, N R Sharma. 1985. A survey of rice diseases in Bangladesh. Tropical Pest Management 31(3): 208-213.

Momotaz, R. 2005. Development and standardization of screening method for resistance to bakanae disease of rice MS thesis, Department of Plant Pathology, SherE-Bangla Agricultural University, Dhaka 1207. Bangladesh.

Nath, R, P Neergaard, S B Mathur. 1970. Identification of Fusarium species on rice seeds as they occur in blotter test. Proceedings of International Seed Testing Association 35: 121-141.

Ou, S H. 1985. Rice disease, 2nd edition.Commonwealth Mycological Institute, Kew, England.p. 380.

Santos, L G. 1957. A survey of the seed-borne fungi of rice.BS thesis, College of Agriculture, University of Philippines.

Sarker, B B. 1986.Controlling bakanae (Bak) and foot rot disease with fungicide seed treatment. International Rice Research Notes 11 p. 3.

Sasaki, T. 1987. Epidemiology and control of rice bakanae disease. Bull. Tohoku Natn. Agric. Exp. Sta. No. 74: 1-47

Singh, R and S Sunder. 1997. Foot rot and bakanae of rice: Retrospects and prospects. Int. J. Trop. Plant Disease 15: 153-176.

Sunder, S, Satyavir and A Singh. 1998. Evaluation of fungicides for the management of bakanae disease of rice. J. Mycology Plant Path. 28(3): 251-58.

Shakahwath, S. 2009. Epidemiology and management of bakanae disease of rice. PhD thesis, Department of Botany, Life and Earth Science Group, National University, Gazipur, Bangladesh.

Winter, W E, S B Mathur, P Neergaard. 1974. Seed-borne organisms of Argentina: A survey. Plant disease Rept 58: 507-511.

Wada, T, S Kuzuma and M Takenaka. 1991. Sensitivity of fusariummoniliforme isolates to pefurazoate. Ann. Phytopath. Soc. Japan. 56: 449-456. 